\title{
EDUCAÇÃO ESCOLAR INDÍGENA MANIFESTADA EM INTERVENÇÃO ARQUITETÔNICA: REFLEXÕES A PARTIR DE UMA ESCOLA KAINGANG
}

NAUÍRA ZANARDO ZANIN ${ }^{1}$

UFFS, BRASIL

http://orcid.org/0000-0001-8671-6445

FERNANDA MACHADO DILL ${ }^{2}$

UFSC, BRASIL

http://orcid.org/0000-0002-6294-6091

\begin{abstract}
RESUMO: $O$ artigo apresenta reflexões sobre espaços escolares indígenas a partir da intervenção arquitetônica para a Escola Indigena de Educação Básica Cacique Vanhkre, localizada na Aldeia Sede da Terra Indígena Xapecó, municipio de Ipuaçu, Santa Catarina. A escolha dessa obra deve-se à representatividade de sua arquitetura, tanto para a comunidade indígena, quanto para a sociedade envolvente. O principal objetivo é problematizar as relações entre as propostas arquitetônicas e a educação escolar indígena, identificadas como meios de afirmação cultural. A análise dirige-se à participação da comunidade no processo de projeto arquitetônico, à apropriação dos espaços e às alterações decorrentes, bem como ao estudo das formas arquitetônicas, sua imagem na paisagem cultural e os significados atribuídos pelos sujeitos. Para tanto, foram utilizados referenciais bibliográficos, publicações na mídia, análise documental, observações e entrevistas abertas e semiestruturadas com professores, estudantes formados e lideranças da aldeia. Como resultados são apresentadas considerações sobre o desenvolvimento de projetos arquitetônicos junto a comunidades indígenas, enfocando o desenho de espaços escolares e sua relação com a proposta de educação indígena específica e diferenciada.
\end{abstract}

PALAVRAS-CHAVE: intervenções arquitetônicas, comunidades indígenas, espaço escolar, Povo Kaingang

ABSTRACT: The article presents reflections about indigenous school spaces from the architectural intervention at the Indigenous School of Basic Education Cacique Vanhkre, located in the Aldeia Sede da Terra Indigena Xapecó, municipality of Ipuaçu, Santa Catarina. The selection of this school is due to the representativeness of its architecture, both for the indigenous community and for the surrounding society. Its main objective is to problematize the relationship between architectural proposals and indigenous school education, identified as a mean of cultural statement. The analysis is aimed at community participation in the architectural design process, the appropriation of spaces and the derived modifications, as well as the study of architectural forms, their image in the cultural landscape and the meanings attributed by the subjects. For this purpose, bibliographic references, media publications, document analysis,

\footnotetext{
${ }^{1}$ Doutora em Arquitetura e Urbanismo pela Universidade Federal de Santa Catarina (2018). Atualmente é professora adjunta da Universidade Federal da Fronteira Sul e Pesquisadora do Núcleo de Dinâmicas Urbanas e Patrimônio Social (NAUI) da UFSC, do Instituto Nacional de Ciência e Tecnologia Brasil Plural (IBP). E-mail: nauira@nauira.arq.br

${ }^{2}$ Doutora em Arquitetura e Urbanismo pelo Programa de Pós graduação em arquitetura e Urbanismo da UFSC. Atualmente realiza pesquisa em nível de Pós doutorado na área de categorias de análise socioespacial em etapas preconcepção no processo de projeto em arquitetura e urbanismo. E-mail: fernanda.dill@gmail.com
}

ZANIN, Nauíra Zanardo; DILL, Fernanda Machado. Educação escolar indígena manifestada em intervenção arquitetônica: reflexões a partir de uma escola Kaingang. Espaço Ameríndio, Porto Alegre, v. 15, n. 1, p. 134-159, jan./abr. 2021. 
observations and open and semi-structured interviews with teachers, trained students and village leaders were used. As results, considerations about the development of architectural projects with indigenous communities are presented, focusing on the design of school spaces and their relationship with the specific and differentiated indigenous education proposal.

KEYWORDS: architectural intervention, indigenous communities, school space, Kaingang People 


\section{Introdução}

No presente artigo, buscamos compreender as arquiteturas inseridas em comunidades indígenas a partir de reflexões acerca desse tipo de intervenção, enfocando principalmente as repercussões atuais dentro das aldeias. Para nutrir nossa visão histórica, utilizamo-nos de autores que tecem críticas acerca de intervenções que alteraram as relações socioespaciais internas das aldeias, como Silvio Coelho dos Santos (1975) e Costa e Malhano (1985). Tais autores retratam uma realidade anterior ao reconhecimento dos direitos indígenas, que teve como marco a Constituição Federal de 1988 (BRASIL, 1988). Naquele período, o ponto principal dessa crítica assentava na descaracterização da organização socioespacial como uma estratégia de assimilação cultural e de controle por parte dos agentes do SPI (Serviço de Proteção ao Índio) e FUNAI (Fundação Nacional do Índio). Essas intervenções objetivavam a integração dos indígenas à sociedade nacional, imprimindo nas aldeias alterações significativas na distribuição das moradias, por exemplo, que deixavam de corresponder às organizações próprias, as quais tinham como base as relações de parentesco e de hierarquia interna, e passavam a ocupar espaços e formas que facilitassem o controle e a vigilância. Contudo, Santos (1975) destaca que, em alguns casos, essas populações procuravam subverter esse tipo de situação, buscando manter minimamente seu modo de vida, com a utilização de duas casas, uma junto ao posto indígena, e outra junto à área de cultivo, construída por eles com os materiais do lugar, onde podiam utilizar o fogo e ter mais liberdade. Em estudos recentes, verifica-se que, em intervenções habitacionais junto a povos indígenas, ainda ocorre esse tipo de situação (ZANIN, 2006; CARRINHO, 2010; CARVALHO, 2013).

As escolas, por sua vez, surgem nas aldeias como uma ferramenta voltada à integração das populações indígenas. Contudo, esse papel da escola foi se alterando, a ponto de ter sua relevância destacada dentro das comunidades como um instrumento de fortalecimento na luta por seus direitos (ALTINI, 2014; DALMOLIN, 2004). É nesse sentido que trazemos a discussão sobre o espaço escolar indígena como um tipo de intervenção arquitetônica que pode refletir alguns anseios da comunidade na qual se insere.

Para tratar desse tema, escolhemos o caso da Escola Indígena de Educação Básica Cacique Vanhkre (EIEB Cacique Vanhkre), localizada na Aldeia Sede da Terra Indígena Xapecó (TI Xapecó). A TI é composta por 16 aldeias da etnia Kaingang e uma aldeia Guarani. A escola foi escolhida como objeto de estudo por sua representatividade simbólica, identificada tanto dentro da aldeia, como perante a sociedade envolvente. Suas edificações compõem um complexo que marca a paisagem e a imagem da aldeia. Abordamos o processo de projeto por meio do qual a atual escola foi constituída e as relações dessa edificação com aspectos culturais, educacionais e simbólicos da etnia Kaingang.

Conscientes das lutas e dos avanços sucessivos voltados ao projeto de espaços escolares em comunidades indígenas para que considerem especificidades étnicas, culturais e socioambientais, delineamos um 
breve histórico das transformações promovidas nos espaços de educação formal dessa comunidade. Nesse sentido, destacamos a origem dessa intervenção, cujos atores foram também integrantes da comunidade, em um contexto histórico específico de ampliação de direitos relacionados à educação indígena, contando, ainda, com uma articulação política favorável.

Como método de pesquisa, investigamos referências bibliográficas, publicações na mídia e documentos (incluindo projetos arquitetônicos). Também realizamos levantamento fotográfico, observações e entrevistas abertas e semiestruturadas com professores, antigos estudantes e lideranças da aldeia.

Esperamos que esse estudo possa contribuir com o diálogo interdisciplinar necessário para acolher a complexidade inerente às intervenções arquitetônicas em comunidades indígenas.

\section{Considerações sobre os avanços legislativos com destaque ao espaço escolar indígena}

A presença de escolas em agrupamentos indígenas no Brasil é referida inicialmente às iniciativas missionárias, as quais atuavam a favor da desagregação e dominação dessas populações. Tassinari (2008) expõe, nas ações missionárias do século XIX, o direcionamento da educação ao ensino de ofícios para a formação de mão de obra capaz de tornar produtivos os aldeamentos. Rosa (2009) considera que as formas indígenas de educação foram invisibilizadas e destituídas no processo de inserção do ensino escolarizado.

Segundo Tassinari (2008), com a criação do Serviço de Proteção aos Índios e Localização de Trabalhadores Nacionais (SPILTN), em 1910, as ações se voltaram à "proteção" dos indígenas em seu processo de integração à sociedade nacional. A autora traz, sob o olhar da antropologia, momentos marcantes das políticas de educação escolar indígena em três diferentes períodos do século XX:

Na década de 1930, com o modelo do Serviço de Proteção do Índio (SPI), davam continuidade ao processo civilizatório e de integração das populações indígenas que, em decorrência disso, tornavam-se dependentes das ações governamentais.

$\mathrm{Na}$ década de 1960, com o modelo da Fundação Nacional do Índio (FUNAl), ocorre um avanço no pensamento antropológico sobre educação e infância indígenas. Mesmo com a continuidade de políticas de assimilação cultural, nas escolas verifica-se o ensino bilíngue e a presença de monitores indígenas, o que direciona esforços para a luta por direitos relacionados a uma educação diferenciada pela valorização cultural.

$\mathrm{Na}$ década de 1990, a partir dos desdobramentos dos direitos conquistados com a Constituição de 1988 (CF/88), como o Decreto n $^{\circ} 26$, de 4 de fevereiro de 1991 (BRASIL,1991) e a Lei de Diretrizes e Bases da Educação Nacional - LDB/96 (BRASIL, 1996), inicia-se uma nova etapa na educação indígena no Brasil, a qual valoriza a diversidade indígena ao reconhecer especificidades culturais e identidades étnicas. 
Esse reconhecimento legislativo, marcado pela $\mathrm{CF} / 88$, dos direitos indígenas a uma educação que contemple "suas línguas maternas e seus processos próprios de aprendizagem" (BRASIL, Art. 210. $\S 2^{\circ}$,), desencadeou sucessivos avanços para a garantia de uma educação diferenciada, bilíngue, específica e intercultural, construída com a participação das comunidades indígenas, contemplando, também em termos de infraestrutura, os espaços físicos nos quais essa educação deveria acontecer.

Zanin, Silva e Cristofoli (2018) apresentam regulamentações e legislações que indicam a necessidade de participação das comunidades nas definições sobre tais espaços, bem como a indicação de que se considerem aspectos relacionados às práticas construtivas de cada grupo. Ademais, as condições ecológicas também aparecem relacionadas ao processo educativo, uma vez que compõem o ambiente de ensino escolar. Dentre os documentos destacados, citamos aqui: Resolução CEB n. ${ }^{\circ} 3$, de 10 de novembro de 1999, do Conselho Nacional de Educação; Cadernos Secad, volume 3, intitulado "Educação Escolar Indígena: diversidade sociocultural indígena ressignificando a escola" (BRASIL, 2007); Resolução CNE/CEB n. ${ }^{\circ}$ 5, de 22 de junho de 2012, a qual define as Diretrizes Curriculares Nacionais especificamente para a Educação Escolar Indígena na Educação Básica; e o Plano Nacional de Educação (PNE - Lei n. ${ }^{\circ} 13.005$, de 25 de junho de 2014).

Em tais documentos, os quais regulamentam e orientam as ações relacionadas às estruturas físicas de espaços escolares indígenas, podemos constatar o avanço na consideração de que a educação diferenciada, específica e intercultural também depende de ambientes construídos e naturais, vinculados à comunidade na qual essa educação acontece. Além disso, enfatizamos a necessidade de se estudar meios pelos quais tais especificidades podem ser contempladas no desenho arquitetônico dos espaços escolares. Zanin (2018) apresenta documentos e relatos que afirmam a vontade das comunidades indígenas em participar do desenho arquitetônico de suas escolas; contudo, verifica que ainda existem vários entraves para viabilizar essa participação de forma efetiva, mesmo que esteja previsto em legislações e regulamentações.

Diante dessa realidade, torna-se relevante apresentar e discutir o caso da EIEB Cacique Vanhkre, uma escola cujo processo de projeto arquitetônico buscou contemplar os anseios da comunidade escolar, proporcionando uma aproximação prática ao que vemos indicado nos documentos citados.

\section{Cultura Kaingang e TI Xapecó}

O Povo Kaingang, assim como outros da família linguística Jê, apresenta uma organização social dualista, patrilinear, exogâmica e matrilocal (TOMMASINO; FERNANDES, 2001), ou seja, é composta por dois grupos de linhagens de parentesco transmitidas pelo pai aos descendentes, nos quais as alianças matrimoniais sempre se dão entre 
indivíduos pertencentes às metades opostas; após o casamento, o noivo vai morar com os pais da noiva.

As metades criadoras da sociedade recebem os nomes dos heróis mitológicos Kamé e Kairu. No mito de origem coletado por Telêmaco Borba (1908), encontra-se uma versão da cosmologia dualista kaingang: Nesse mito, Kamé e Kairu produzem não apenas as divisões entre os homens, mas também a divisão entre os demais seres e elementos da natureza.

Dessa forma, segundo a tradição kaingang, o Sol é Kamé, e a Lua é Kairu; o pinheiro é Kamé, e o cedro é Kairu; o lagarto é Kamé, e o macaco é Kairu (BORBA, 1908). Essa divisão está embasada na noção de complementaridade entre as metades ${ }^{3}$, com o intuito de valorizar a beleza existente na composição entre as diferenças e os opostos. Esse princípio dialético marca continuamente o discurso kaingang, o qual aponta para a "aversão e o horror à junção de coisas iguais porque elas são estéreis" e que dissemina a ideia de que "a fertilidade vem da união dos princípios contrários" (VEIGA, 2000, p. 79).

Ao enfocar os papéis sociais, percebe-se que se por um lado há equidade no que se refere ao gênero, haja vista que homens e mulheres desempenham diferentes papéis sem apresentar uma situação de hierarquia entre eles, o mesmo não se pode dizer das diferenças relacionadas à idade. Os anciãos e as anciãs (kofá $\left.{ }^{4}\right)$ das comunidades kaingang detêm um status de muita sabedoria e respeito exercendo funções que só eles e elas podem realizar. Antes da chegada de postos de saúde às aldeias, cabia às mulheres mais velhas o serviço de parteiras, os primeiros cuidados à mãe e ao recém-nascido, a criação e educação das crianças, a orientação e cuidados com a amamentação (NÖTZOLD, 2004). Outro papel pertencente aos mais velhos é o de Kujá. Esse status identifica a pessoa que faz as curas espirituais, conhece as doenças e os remédios e obtém tal conhecimento através de uma energia, uma força, um guia, um espírito, ou de avisos dados pelos animais da floresta. "O Kujá, faz benzimentos, simpatias para resolver problemas de saúde, bem como da comunidade" (NÖTZOLD, 2004, p. 42).

Quanto à organização política, tradicionalmente os chefes kaingang detêm pouca autoridade. Esse papel se destaca apenas em ocasiões especiais, e sua autoridade está baseada na generosidade para com os membros do seu grupo. Ao cacique cabia ainda liderar seus seguidores em empreendimentos coletivos e mediar conflitos intragrupais (NACKE, 2007).

Entre os rituais principais dos Kaingang, destaca-se o Ritual do Kiki, Kikikoi, Festa do Kiki ou Culto aos Mortos. Trata-se de uma festa para os mortos recentes, a qual é organizada pelos consanguíneos do morto em

\footnotetext{
${ }^{3}$ As grafias das metades clânicas kaingang aparecem de formas diferentes de acordo com cada pesquisador. Veiga (1994) estabelece Kame e Kanhru; Telêmaco Borba (1908) grafava Camé e Kayrucrés; Baldus (1937) utilizava a grafia Kadnyerú e Kamé. Tais distinções podem ser atribuídas tanto às variações dialetais da língua Kaingang quanto aos diferentes períodos dos registros. Para os fins deste trabalho, optamos pela grafia Kamé e Kairu, pois são assim escritas nas comunidades que são objetos desta pesquisa.

${ }^{4}$ Esta palavra em kaingang pode ser utilizada para denominar ancião ou anciã e é também utilizada para fazer referência aos avós.
} 
sua homenagem e integra durante o ritual as metades Kamé e Kairu. Esse culto é apontado como a base e a expressão mais forte da cultura espiritual dos Kaingang e a manutenção desse ritual é fundamental para a manutenção da cultura desse povo (SILVA, 2011 ).

As informações a respeito dos assentamentos humanos constituídos pelos grupos Kaingang, antes do contato com os não indígenas, são o resultado de pesquisas arqueológicas que vêm se desenvolvendo desde o século XIX. Percebe-se que as alterações na forma de apropriação dos espaços para a moradia, ligadas às mudanças climáticas, favoreciam o deslocamento das populações de acordo com as estações do ano e exigia o emprego de materiais e formas de ocupação que pudessem proteger os povos do frio especialmente, mas também de perseguições desencadeadas pelos conflitos com os colonizadores. As organizações vão, conforme exposto a seguir, desde habitações a céu aberto, passando por abrigos subterrâneos e semissubterrâneos até a construção de abrigos sobre o solo.

A primeira forma de habitação utilizada pelos Kaingang, aproximadamente há seis mil anos, é identificada como acampamentos a céu aberto, nos quais eles dormiam sobre pedras, na maioria dos casos ao ar livre, não sendo comum, de acordo com estudos arqueológicos, a ocupação de cavernas e abrigos sob rochas (NÖTZOLD, 2003). A partir das transformações culturais ocorridas em função da adaptação ao clima e ao relevo, os grupos começaram a construir estruturas subterrâneas, as quais são utilizadas para fins residenciais, rituais e de armazenamento de alimentos.

O pesquisador na área de Arqueologia no Rio Grande do Sul, Pedro Ignácio Schmitz (2010), coloca que os assentamentos podiam compor-se de choupanas construídas com materiais perecíveis, na superfície do solo, sem apreciáveis modificações do solo ou do entorno, ou podiam implicar movimentação intensa da terra, rebaixando o piso de suas habitações, aterrando seus arredores, acumulando terra para formar montículos de diversos tamanhos e finalidades, construindo taipas de terra para fechar grandes recintos de uso comunitário que constituíam as estruturas subterrâneas e seus acompanhamentos (SCHMITZ et al, 2010). A Figura 1 exemplifica a descrição anterior a partir de um estudo de Schmitz e de seus colaboradores em São José do Cerrito, Santa Catarina (2010).

Figura 1: Estrutura subterrânea e sua representação gráfica.
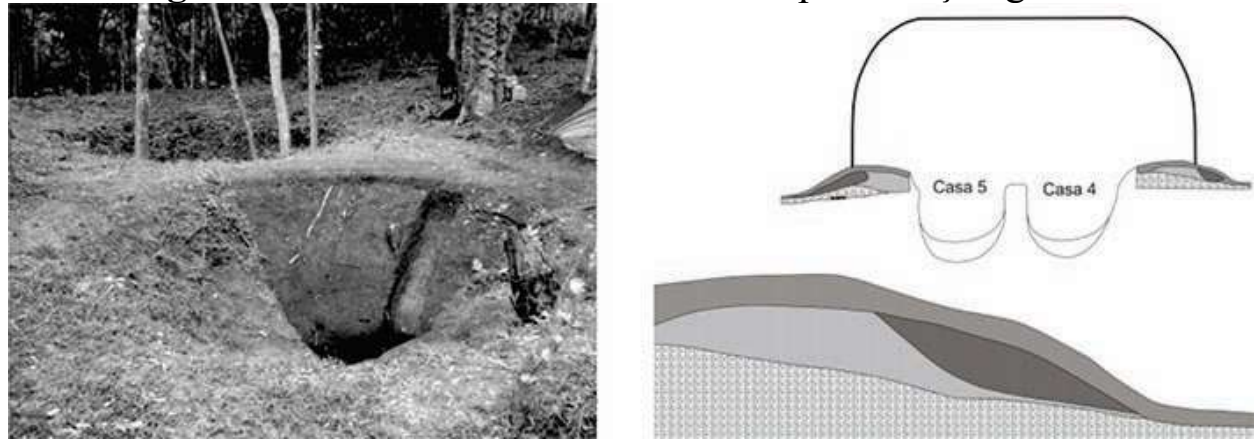

Fonte: Schmitz et al (2010, p. 42 e p. 58). 
As pesquisas de Reis (2007) apontam para uma problemática arqueológica no que diz respeito às estruturas subterrâneas: uma vez estabelecida a caracterização morfológica das estruturas subterrâneas através da descrição dos sítios arqueológicos, é preciso encaminhar o problema para sua identificação funcional (REIS, 2007). As informações, normalmente contidas em material etnográfico, são utilizadas pelos arqueólogos para a formação de quadros interpretativos. Dessa forma, esses cientistas relacionam os resultados de suas pesquisas aos conhecimentos sobre o funcionamento de sistemas culturais.

Sobre as estruturas subterrâneas, Reis (2007) evidencia que a utilização de fontes etnográficas se torna quase impraticável; primeiro, por serem escassas e fragmentárias; segundo, por ser "impossível medir a distância temporal entre o passado arqueológico e o presente etnográfico" (REIS, 2007, p. 185). Além disso, a autora busca em outras áreas americanas, relacionadas a sítios com estruturas subterrâneas, as fontes para formular hipóteses sobre a realidade catarinense.

A hipótese de utilização das estruturas subterrâneas como habitação, nesse caso, pode ser, de início, uma proposta pela simples abundância com que ocorrem, pela articulação das unidades entre si (sugerindo função integradora própria de moradias) e pela inexistência de outros espaços de habitação que pudessem se articular aos aglomerados em causa (REIS, 2007, p. 186).

Na mesma perspectiva, a pesquisa aponta outras funções possíveis para determinados tipos e tamanhos de estruturas: 1) as pequenas e médias caracterizam-se como habitação; 2) as estruturas grandes podem estar relacionadas a centros cerimoniais; 3 ) as estruturas geminadas podem ter sido ocupadas por grupos familiares, compostos de duas ou três famílias nucleares; 4) as galerias, entre as estruturas subterrâneas, poderiam ser utilizadas como estratégia de proteção tanto do frio quanto de invasores; 5) os aterros, hipoteticamente, podem ser caracterizados com função funeral. A Figura 2 contém algumas plantas desses sítios arqueológicos pesquisados e ilustram as estruturas descritas anteriormente.

Figura 2: Sítios arqueológicos em Santa Catarina.

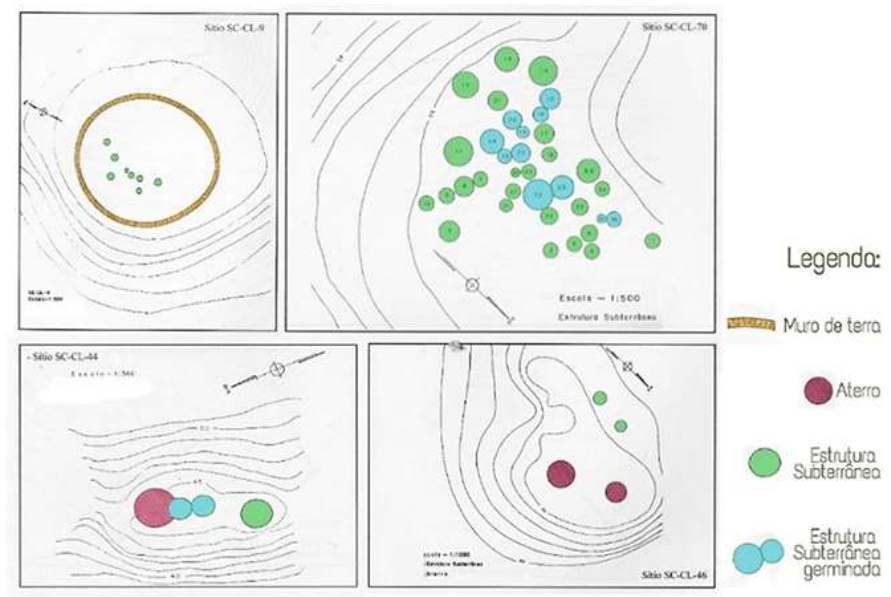

Fonte: Adaptado de (REIS, 2007). 
Segundo a descrição de D'Angelis e Veiga (2003) sobre a cova circular que delimitava a estrutura subterrânea, erguia-se uma cobertura de folhas sustentada em uma armação de madeira, em parte fixada na base da casa, e em parte fixada nas bordas laterais da cova, inclusive com o auxílio de pedras (conforme Figura 3 e Figura 4). Em algumas casas, os arqueólogos mencionam ter encontrado um revestimento de piso e, em outras, revestimento em pedra nas paredes ou em parte delas (D'ANGELIS e VEIGA, 2003).

Figura 3: Suportes de vigamento do telhado e Casa subterrânea grande.

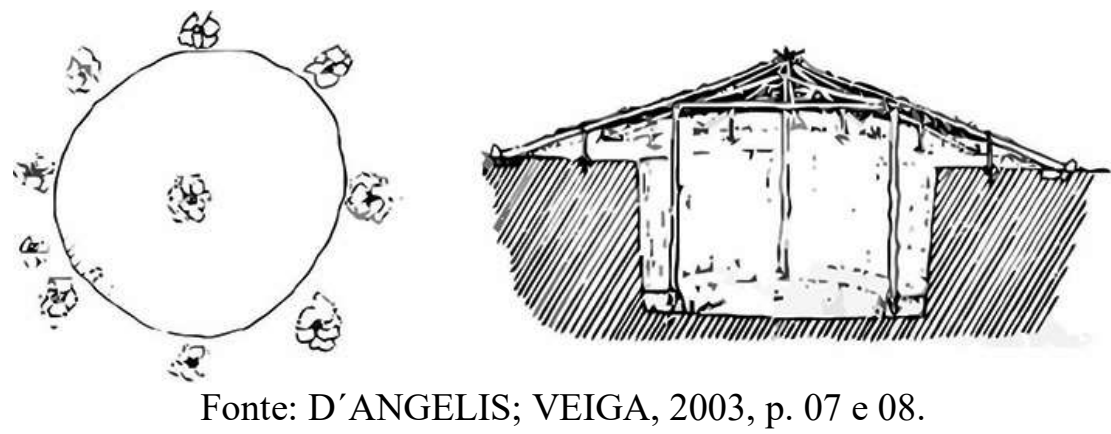

Figura 4: Casas subterrâneas kaingang.
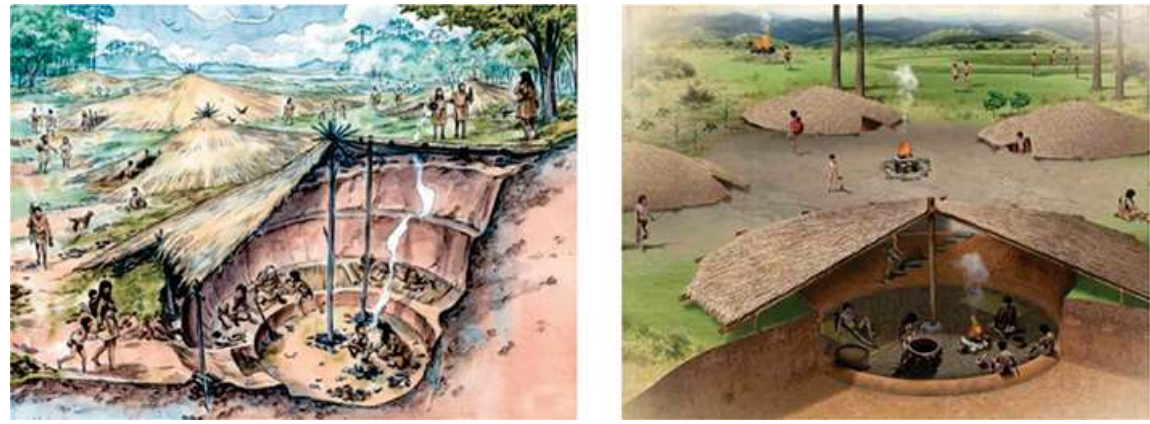

Fonte: (MULTIPLICA, 2016).

Os mesmos autores salientam que, em um número significativo de sítios arqueológicos com casas subterrâneas isoladas, é comum encontrar conjuntos dessas casas, seja formando pares, seja formando verdadeiras aldeias de mais de cinco casas, sendo vários os agrupamentos entre oito e dez delas. Também há casos com mais de vinte casas em um mesmo lugar.

As informações apresentadas até aqui possibilitam a interpretação da arquitetura possivelmente criada pelos Kaingang que utiliza, segundo Rapoport (1971), a capacidade de absorção de calor da terra e garante a eficiência dessas edificações no amortecimento das variações anuais de temperatura, como também sugere a configuração espacial dos assentamentos (Figura 5), revelando dinâmicas sociais a partir de práticas cerimoniais. 
Figura 5: Assentamento característico kaingang.
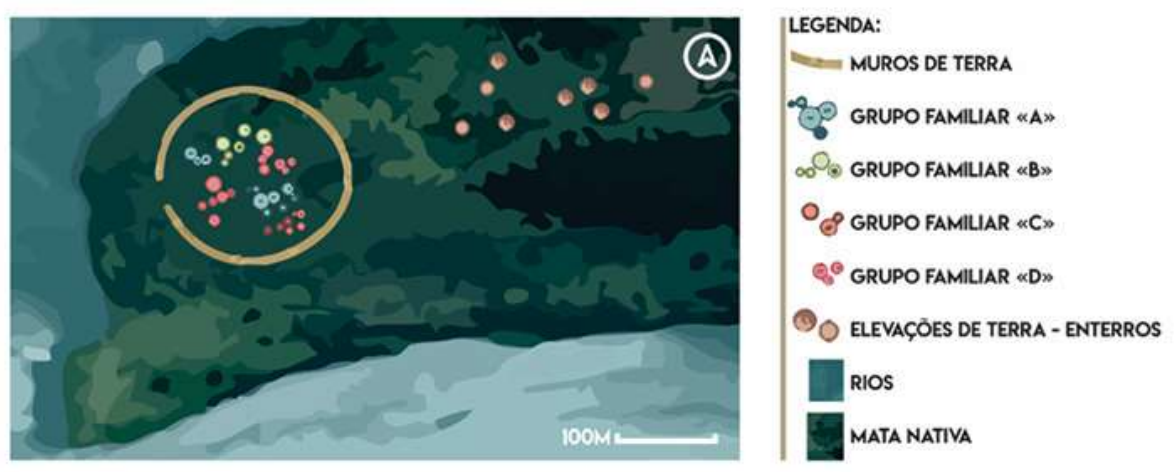

Fonte: DILL, 2019.

O assentamento característico dos Kaingang, de acordo com a descrição anterior, espacializada na figura acima, poderia ser caracterizada por um agrupamento de estruturas subterrâneas posicionadas não aleatoriamente, mas de acordo com a matrilocalidade e a organização dos grupos familiares. Os enterros são feitos em local próximo, mas não em meio às moradias. Existe a delimitação da área de moradias feita com um muro de terra, o qual tem o objetivo de proteger o grupo de possíveis ataques de animais. Por fim, observa-se o posicionamento do agrupamento próximo ao rio, em meio à mata menos densa e protegido do vento por vegetações mais densas e morros.

Posteriormente, de acordo com D'Angelis e Veiga (2003), uma das primeiras descrições de uma grande casa kaingang aparece no relatório do engenheiro alemão Franz Keller, a serviço do governo imperial, com data de 1867. Sobre os índios habitantes dos aldeamentos de São Pedro de Alcântara e São Jerônimo (nas margens do médio Tibagi, onde atualmente estão as áreas kaingang de Apucarana e de São Jerônimo, no norte paranaense), aos quais chamou de "Ca-en-gagn ou Coroados", informou que seus ranchos eram cobertos de folhas de palmeira, apresentavam na secção uma forma ogival mais pontuda, isto é, eram mais altos em proporção à largura do que os dos Cayoás. O chão batido tinha um declive suave dos dois lados para o centro, estando em conformidade com a inclinação necessária para as camas, representadas por imensos pedaços de casca grossa de um pau, e tão lisas que parecem tapetes de caoutchoucougutta-percha. No meio das duas fileiras de camas, ficava uma passagem livre, onde cada família fazia o fogo para o preparo das comidas (KELLER, 1974). A Figura 6 foi elaborada com base na descrição da casa kaingang feita por Franz Keller em 1867: 
Figura 6: Casa grande kaingang.
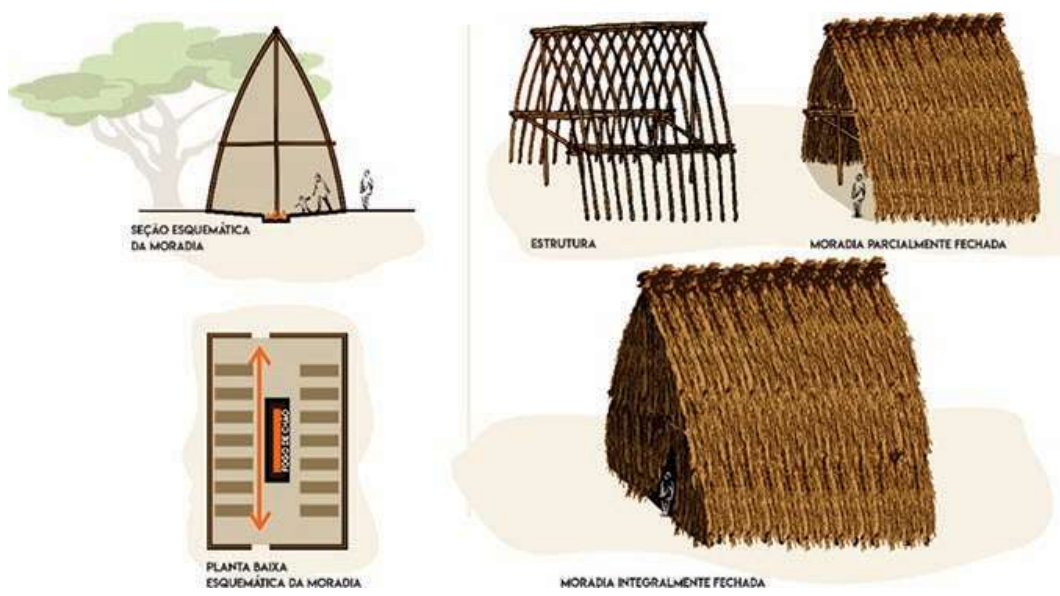

Fonte: DILL, 2019.

Outros autores e relatos confirmam a descrição da grande casa kaingang fechada nos quatro lados (conforme ilustra a planta baixa na Figura 6), com pequenas entradas nas extremidades. Segundo D'Angelis e Veiga (2003), na segunda metade do século XIX, existe uma descrição de uma casa kaingang equivalente feita por Reinhold Hensel, que visitou o toldo de Caseros, no norte do Rio Grande do Sul, em maio de 1865. Nos documentos do século XX, uma das primeiras descrições foi publicada por Gustav von Koenigswald, que visitou os Kaingang do Paraná entre os anos de 1903 e 1904, também com informações e caracterizações semelhantes.

Os acampamentos a céu aberto, as casas subterrâneas e a casa grande kaingang são as possibilidades apresentadas de arranjo residencial e cerimonial das aldeias antes do contato com a sociedade não indígena.

A descrição dos pilares que constituem o Povo Kaingang e a forma como ocupavam o território elucidam a forma de viver dessas populações, as quais construíram uma relação de dependência e respeito com a natureza, encontrando nela sua alimentação, a cura para as doenças, a morada dos espíritos, a origem de seu povo e o local onde eram constituídas as aldeias. A partir de observações recentes, nota-se que "mesmo vivendo em condições impostas pela sociedade nacional, os Kaingang continuam se reproduzindo enquanto grupos etnicamente diferenciados" (TOMMASINO, 1995) e esse movimento na direção da preservação da cultura fica evidente nas práticas contemporâneas.

$\mathrm{O}$ contato dos Kaingang com a sociedade não indígena do entorno teve início, conforme descrito, no final do século XVIII e se efetivou em meados do século XIX. Nesse período, chefes políticos indígenas aceitaram aliar-se a conquistadores brancos, processo esse que colaborou para a pacificação de alguns grupos arredios e a invasão do território kaingang (PIOVEZANA, 2010).

Durante décadas, e até hoje, existem lutas pela terra e pela retomada de territórios tradicionais indígenas não só no oeste catarinense, mas em todo o Brasil. Para os povos indígenas, a terra tem 
um significado de representação da vida social, estando ligada às crenças e ao conhecimento indígena, superando, dessa forma, a função de subsistência e passando a representar um recurso sociocultural (RAMOS, 1995).

Os Kaingang do Oeste Catarinense vivem em cinco áreas indígenas: Terra Indígena Xapecó (TI Xapecó), Toldo Chimbangue, Toldo Imbú, Toldo Pinhal e Aldeia Kondá, conforme o mapa abaixo:

Figura 7: Localização das áreas indígenas no Oeste Catarinense.

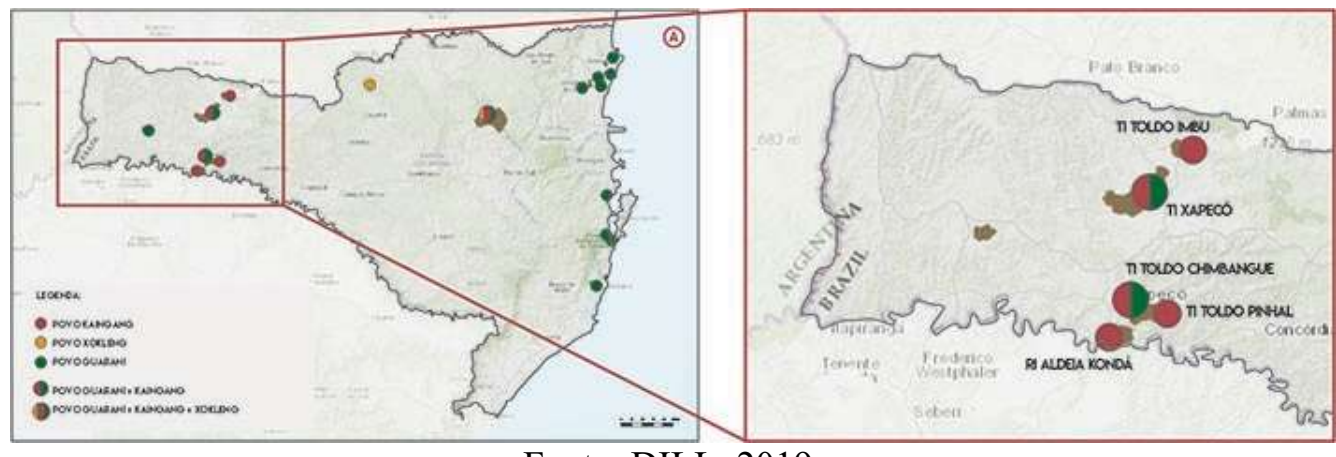

Fonte: DILL, 2019.

A TI Xapecó, local onde a escola analisada se situa, tem sua situação jurídica homologada e registrada no Cartório de Registro de Imóveis desde 1991. Ela abrange parte dos municípios de Abelardo Luz, Entre Rios, Ipuaçú e Bom Jesus e está localizada à margem direita do Rio Chapecozinho e de Rio Chapecó. Faz divisa com os municípios de Ipuaçú e Marema no lado esquerdo (PIOVEZANA, 2010).

Figura 8: Localização da Área da TI Xapecó.

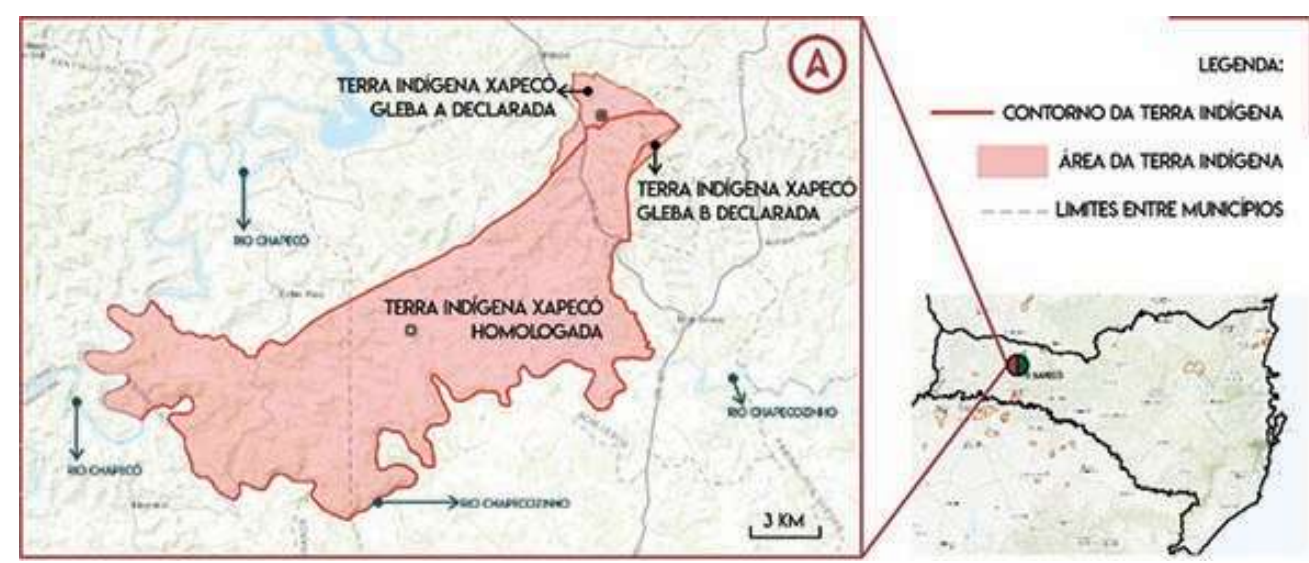

Fonte: DILL, 2019.

Vivem nesta TI indígenas das etnias Kaingang e Guarani, totalizando uma população de aproximadamente 6.000 pessoas (ISA, 2016). Essa população está localizada nas seguintes aldeias: Sede, Olaria, Água Branca, Fazenda São José, Serrano, Aldeia Serro Doce, Pinhalzinho, Baixo Samburá, Linha Matão, Paiol de Barro, João Veloso, Linha Guarani e 
Linha Limeira (NACKE, et al., 2007). Encontra-se, na Aldeia Sede, o complexo escolar analisado nessa pesquisa.

Figura 9: Localização da Aldeia Sede e da EIEB Cacique Vanhkré.

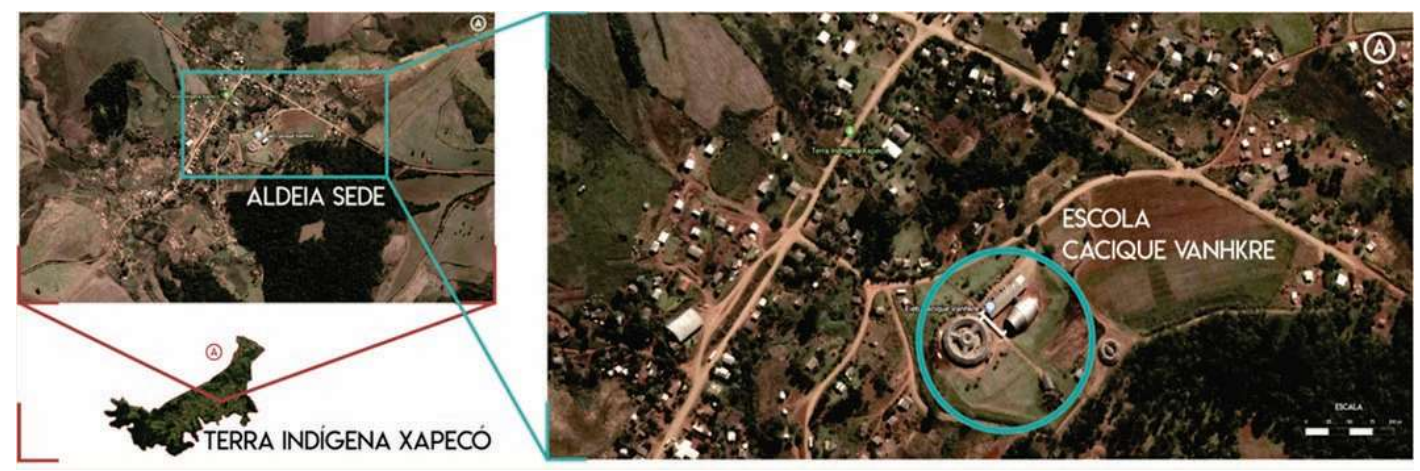

Fonte: Elaborado por Fernanda Dill com base em GoogleMaps (2019).

A Figura 9 localiza a Aldeia Sede no contexto da Terra Indígena Xapecó bem como a EIEB Cacique Vanhkre na Aldeia Sede, evidenciando seu impacto no contexto paisagístico local, o qual é predominantemente formado por vias sem calçamento, moradias unifamiliares, algumas edificações de uso coletivo, como igreja e posto de saúde e manchas de vegetação nativa em meio às lavouras e roças familiares.

\section{EIEB Cacique Vanhkre: uma arquitetura escolar específica}

O principal objetivo deste artigo é refletir sobre as intervenções de arquitetura escolar, problematizando relações entre as soluções arquitetônicas e a educação escolar indígena, ambas identificadas como meios de afirmação cultural. Para isso, utilizamos como objeto de estudo o caso da EIEB Cacique Vanhkre, considerando diferentes aspectos interrelacionados, como o movimento pela construção da escola nova, a participação no processo de projeto, as soluções arquitetônicas resultantes e os significados, os usos e as apropriações por parte da comunidade. Para tanto, iniciaremos nossa análise apresentando um breve histórico da educação escolarizada nessa Tl.

A EIEB Cacique Vanhkre está diretamente ligada ao panorama histórico da educação na Terra Indígena Xapecó, tendo surgido como resultado de uma trajetória de lutas e de conquistas dessa comunidade no sentido de fazer valer, na prática, a legislação que garante o direito à educação considerando as especificidades étnicas. Desde 1912 (NÖTZOLD, 2003), as crianças indígenas contavam com um professor que atendia à comunidade. Em 1947, o professor era o Sr. Felicíssimo Belino, pago pelo Sr. Selistre de Campos, jurista, um dos grandes defensores dos direitos indígenas no Oeste Catarinense (MANFROI, 2012). Nötzold e Rosa (2011) relatam que esse professor ministrava aulas à sombra das árvores, o que é uma interessante referência sobre o uso dos espaços para educação nessa comunidade. 
A primeira escola foi instalada em 1975, sendo denominada Escola Isolada Federal Posto Indígena Xapecó, que, em 1984, passa a ser chamada Escola Isolada Federal Vitorino Kondá. De acordo com relatos de alguns dos entrevistados, o espaço escolar, bem como sua configuração formal junto às secretarias de educação, passou ao longo dos anos por diversas transformações.

Antes da construção da EIEB Cacique Vanhkre, a escola Vitorino Kondá ficava localizada em um local baixo da aldeia, sem visibilidade a partir dos núcleos de moradia. Essa característica é apontada por uma entrevistada como algo negativo com relação à segurança das crianças em seus deslocamentos diários. Outro aspecto levantado é a estrutura convencional não-indígena da antiga escola, que além de precária, não se configurava como um espaço de identificação cultural para os alunos. Por sua vez, o projeto concebido para a EIEB Cacique Vanhkre, a partir de 1998 , e inaugurado no dia 19 de abril de 2000, configurou-se como espaço de afirmação da educação formal que considera as especificidades étnicas e, mais do que isso, valoriza os aspectos culturais fundamentais para a construção da identidade coletiva da comunidade.

Segundo um dos entrevistados, a luta pela construção de uma escola que atendesse à comunidade começou em 1992, com o reconhecimento do ensino bilíngue e a presença de professores kaingang na aldeia. Depois da LDB/96, intensifica-se a argumentação em torno da construção de escolas indígenas diferenciadas. Nesse cenário, em 1998, o movimento acaba se fortalecendo para pensar uma escola diferenciada na TI Xapecó, em busca de meios para construir uma escola que considerasse as necessidades e especificidades culturais do entorno.

A partir da demanda da comunidade escolar, iniciou-se, em 1999, o processo de projeto, integrando a Secretaria do Estado da Educação e do Desporto e o Departamento de Edificações e Obras Hidráulicas da Secretaria de Estado dos Transportes e Obras, com a responsabilidade técnica do arquiteto Ires Lopes da Silva. A comunidade, com a participação de pais, alunos, professores e lideranças, entregou desenhos e conversou sobre o que consideravam importante na nova escola. Um sujeito de destaque nesses diálogos foi o professor Ubiratã, indígena da etnia Xerente, que participou dos diálogos do processo de projeto da escola e contribuiu com alguns dos desenhos em abril de 1999. A Figura 11 e a Figura 12 contêm alguns dos desenhos produzidos na comunidade, os quais foram significativos para a definição das formas arquitetônicas resultantes.

Figura 10: Sequência de representação do tatu.

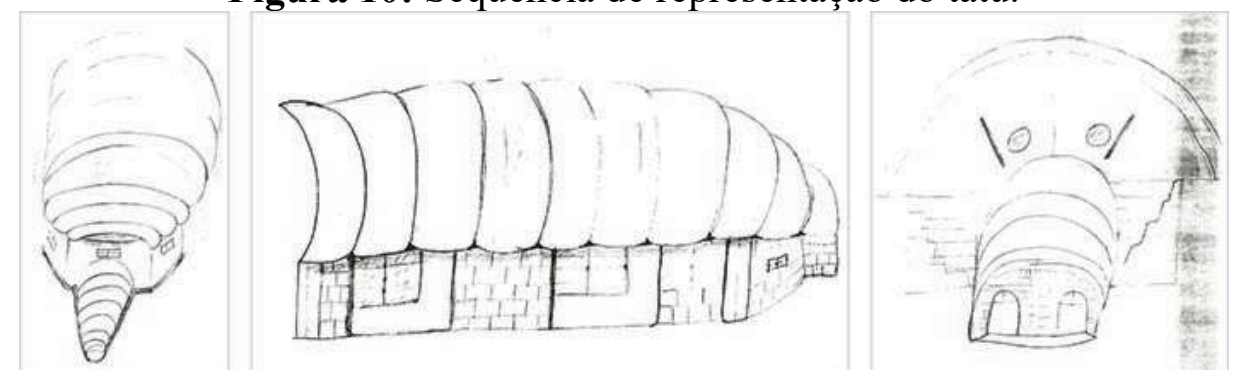

Fonte: Registros do Projeto Arquitetônico n. 2000 do Colégio Estadual Vitorino Kondá 
Figura 11: Sequência de desenhos de aberturas e de materiais.
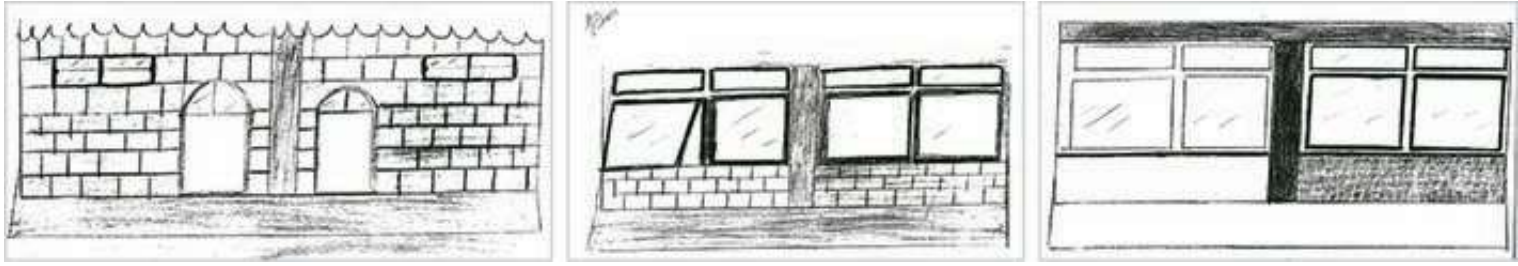

Fonte: Registros do Projeto Arquitetônico n. 2000 do Colégio Estadual Vitorino Kondá.

Figura 12: Sequência de desenhos que representam a forma e os materiais.

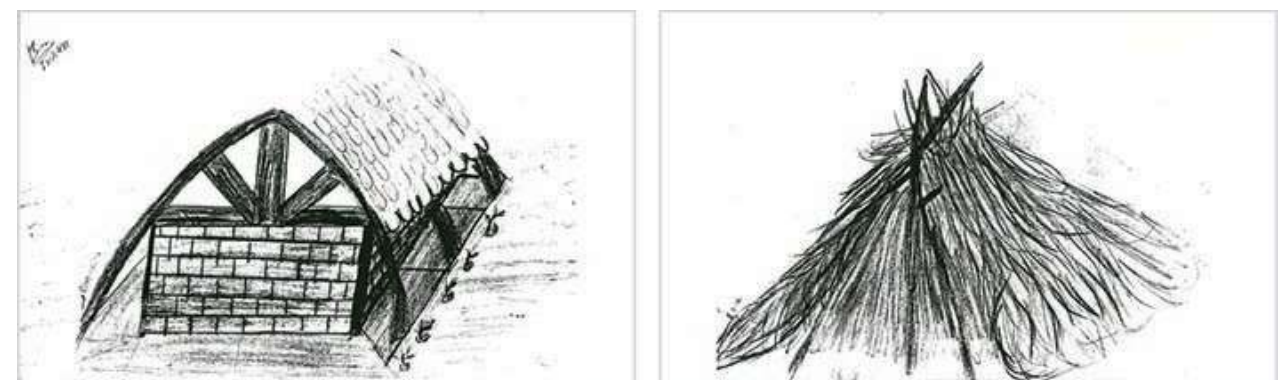

Fonte: Registros do Projeto Arquitetônico n. 2000 do Colégio Estadual Vitorino Kondá.

Esses desenhos representam bem a intenção de se fazer um ginásio em forma de tatu, mas também expressam outras questões, como a materialidade, que pode ser apreciada na perspectiva interna, nas vistas, no uso de cestarias e na alvenaria à vista, no desenho das aberturas (portas com acabamento superior em arco) e na representação de outros materiais naturais, como pode ser observado nos desenhos que se assemelham às coberturas de palha. Em termos formais, ainda consta um desenho em arco ogival, que não comparece na estrutura da escola atual. Por meio desses desenhos, vemos intenções e a tentativa de expressar ideias conceituais que pudessem nortear o projeto.

\section{Arquitetura escolar como manifestação cultural}

A fim de analisarmos a arquitetura resultante desse processo dialogado com a comunidade escolar, utilizamos o memorial descritivo do Projeto Arquitetônico n 2000, datado de 11 de julho de 1999 (SILVA, 1999). Tal versão do projeto apresenta indicações de materiais de acabamentos considerados mais próximos às técnicas construtivas kaingang, mas que são apenas parcialmente observados atualmente nas edificações da escola.

Um dos entrevistados confirmou que algumas das orientações técnicas e alguns dos materiais presentes no projeto foram alteradas no período da execução, a fim de facilitar a construção da escola e de reduzir custos e tempo de execução da obra. No entanto, segundo o mesmo entrevistado, essas modificações, em alguns aspectos, comprometeram 
o uso dos espaços e aumentaram a necessidade de manutenções ao longo do tempo. Esse é o caso da cobertura do ginásio, a qual já foi adaptada algumas vezes e ainda apresenta problemas de infiltração de águas pluviais.

A partir da análise do documento do projeto, das observações feitas no local e dos depoimentos de alguns entrevistados, apresentamos, a seguir, as edificações que compõem o complexo escolar (Figuras 13 e 14): Escola, Ginásio de Esportes e Anfiteatro Kaingang.

Figura 13: Formas das edificações do complexo escolar.

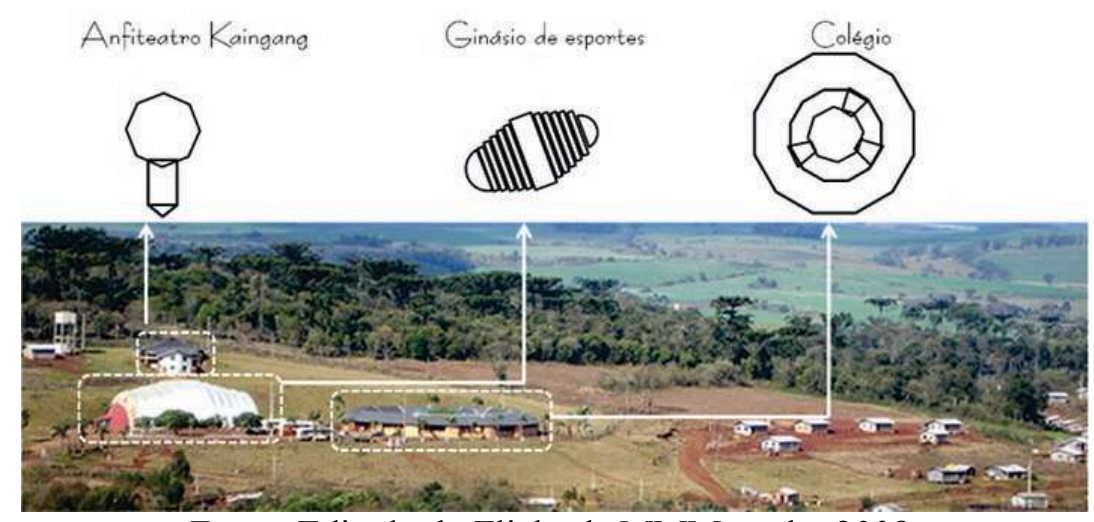

Fonte: Editado do Flickr de MMMarcelo, 2008.

Figura 14: Vista aérea do complexo escolar da EIEB Cacique Vahnkrê.

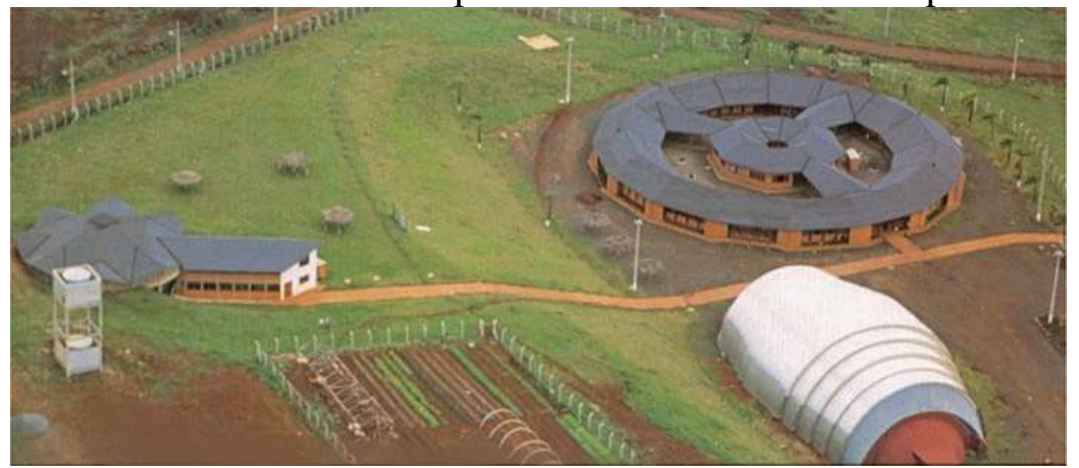

Fonte: Secretaria da Educação e do Desporto de Santa Catarina, 2002.

Com relação às soluções formais, um entrevistado esclareceu que o desenho surgiu ao pensarem na organização social kaingang: o círculo utilizado na escola representa uma das metades (Kairu); o tatu, a outra (Kamé). Além disso, o tatu e a tartaruga são utilizados na alimentação.

A Escola (Figura 15), desenhada em círculo, faz referência à forma urbanística de antigas aldeias (SILVA, 1999), com inspiração em agrupamentos indígenas do tronco linguístico Jê, os quais apresentam formato circular, sendo marcados por forte centralização geométrica, com a casa dos homens ou do cacique localizada no centro (NOVAES, 1983). Seguindo essa forma, a escola caracteriza-se por um círculo composto pelas salas de aula, com a área administrativa ao centro. $O$ pátio configura-se em anel entre esses dois elementos, com circulação coberta periférica. Com relação ao uso e configuração dos espaços da 
Escola, destacamos, ainda, a forma das salas de aula, a qual é decorrente da inserção de espaços intermediários destinados ao fogo de chão. Segundo o memorial arquitetônico consultado, a Escola expressa, ainda, a ideia mítico-filosófica do "Todo" e estiliza a forma da tartaruga (SILVA, 1999).

Figura 15: Escola.
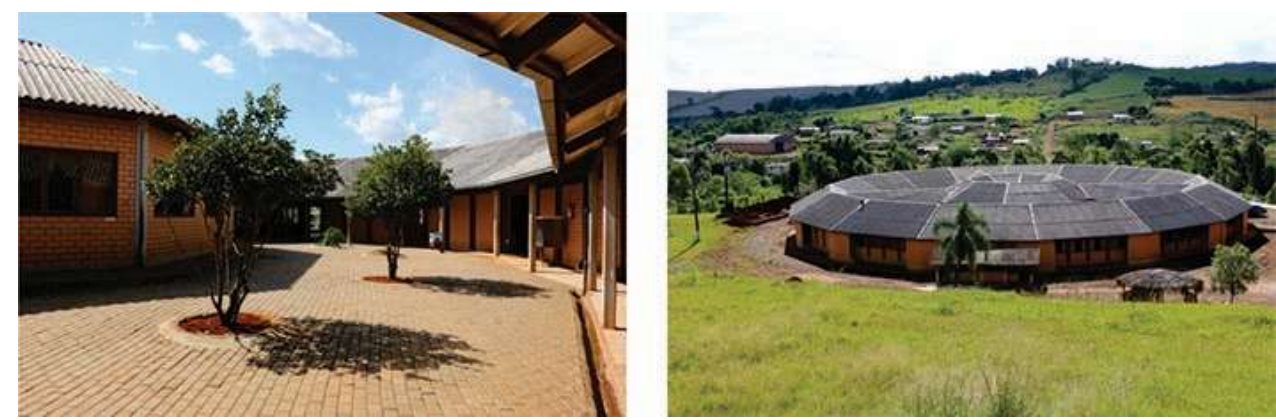

Fotos: Nauíra Zanardo Zanin.

O Anfiteatro Kaingang (Figura 16) possui a mesma inspiração, mas além da referência à forma da tartaruga, contempla características da antiga casa subterrânea, como pode ser observado em seu corte e em fotografias (Figura17). Por fim, o Ginásio de Esportes (Figura 18), com referência formal inspirada na casca do tatu, contempla ainda uma forma abobadada semelhante às antigas construções de varas arqueadas.

Figura 16: Anfiteatro Kaingang.
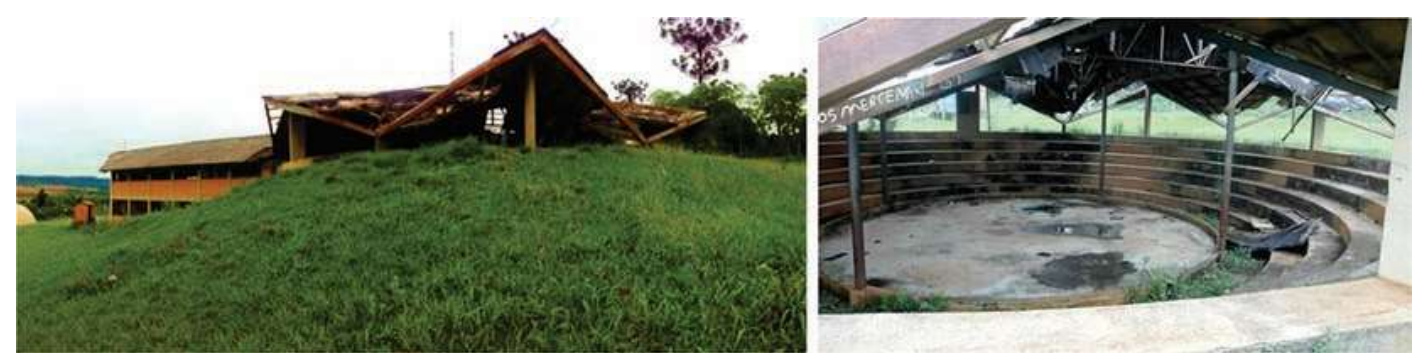

Fotos: Fernanda Machado Dill.

Figura 17: Corte do Anfiteatro Kaingang.

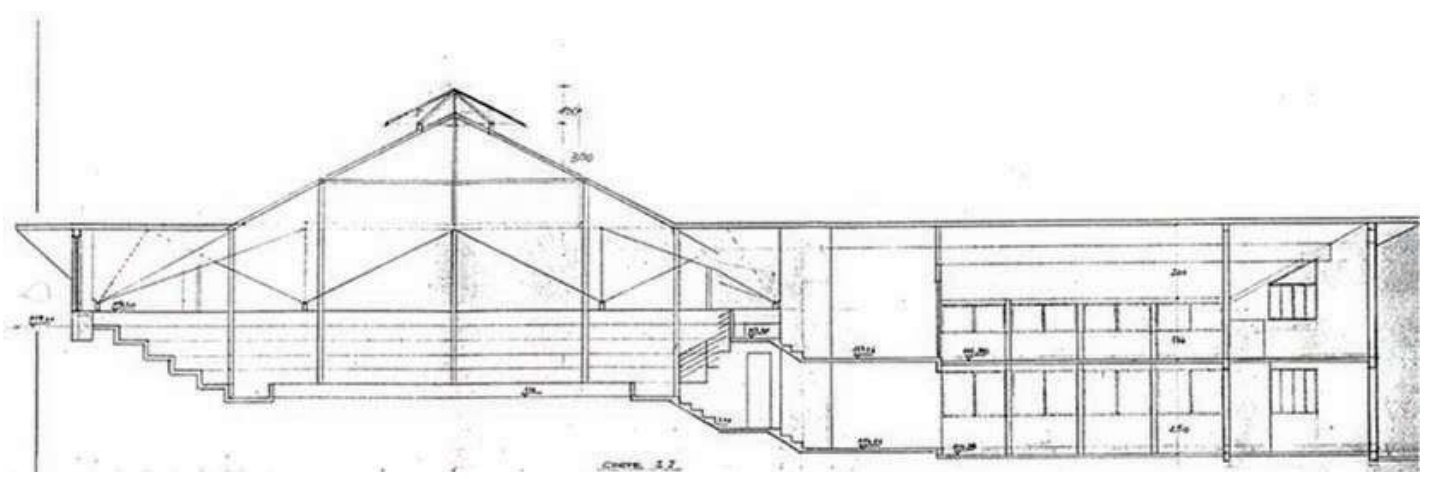

Fonte: SILVA, 1999. 
Figura 18: Ginásio de Esportes.

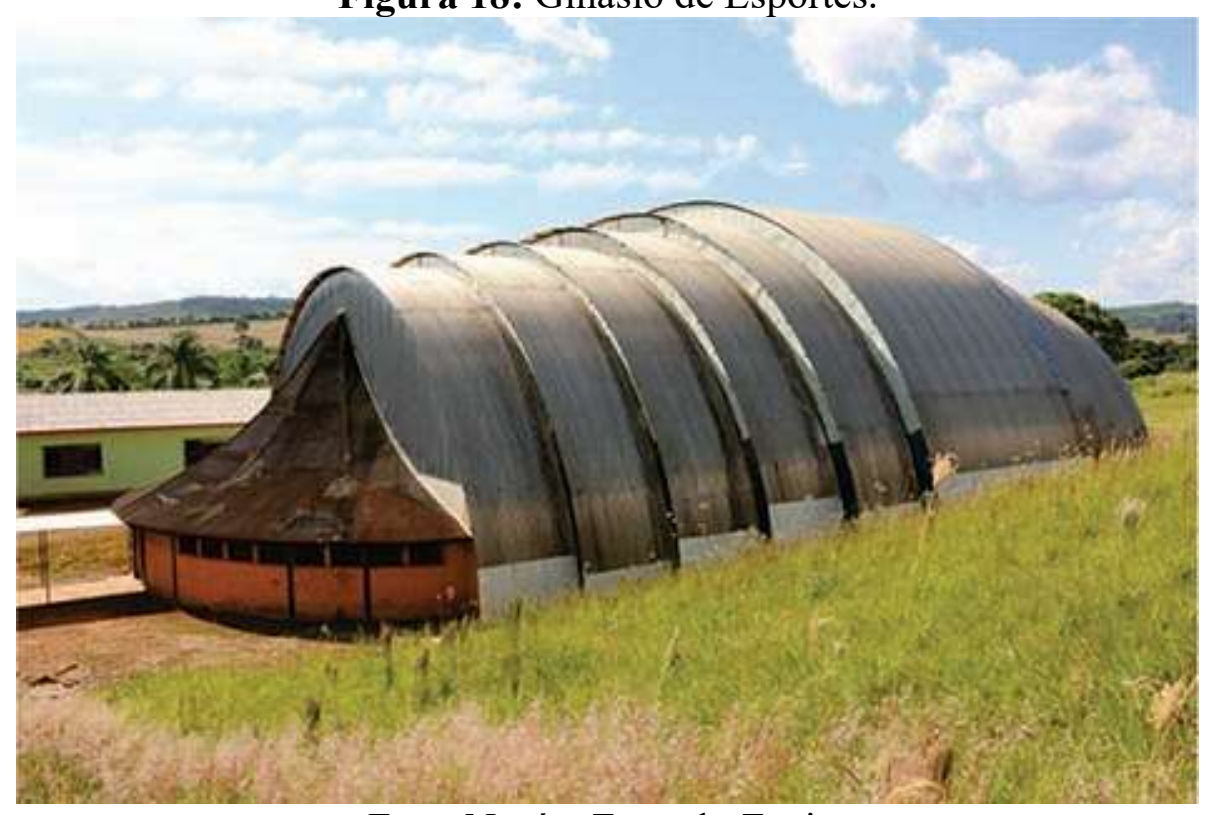

Foto: Nauíra Zanardo Zanin.

\section{Reflexões a partir da intervenção arquitetônica para a EIEB Cacique Vanhkre}

Neste artigo, temos a intenção de refletir sobre o significado da inserção de novas arquiteturas em terras indígenas, como é o caso da EIEB Cacique Vanhkre. Para essa tarefa, apoiamo-nos em alguns referenciais da arquitetura, especialmente naqueles interessados na relação que as pessoas estabelecem com os lugares. Consideramos, apoiadas em Simon Unwin (2013), que a criação de lugar não é exclusividade do fazer arquitetura, pois as pessoas atribuem significados às parcelas do espaço a todo momento. No caso que estamos analisando, verifica-se o protagonismo nas reivindicações pelo espaço e no processo de desenho, pautado pela intenção de fortalecimento cultural. Esses fatores facilitam a identificação do usuário com o lugar. Unwin (2013, p. 23) coloca que "talvez a ideia da participação coletiva seja o aspecto mais importante de pensar na arquitetura como identificação de lugar".

Para Unwin $(2013$, p. XIV), a escolha de lugares vem antes e é mais relevante que a "aparência esculpida das edificações". Ao observarmos a inserção da escola na paisagem da aldeia, verificamos a escolha de um lugar com ampla visibilidade, emoldurado pela mata de araucárias. Então consideramos que não somente as edificações da escola explicitam uma representatividade cultural e simbólica, como também sua própria inserção nessa paisagem reforça isso. Sua arquitetura distingue-se fortemente do contexto das demais construções distribuídas pela aldeia. E é nesse contraste, somado aos significados culturais atribuídos a essa arquitetura, que reside nosso questionamento acerca do que vem sendo realizado em termos de intervenções nessas comunidades. 
Nesse sentido, é importante reconhecer a cultura como algo dinâmico, que reflete a inconstância das mudanças provocadas pelas trocas interculturais. O projeto da EIEB Cacique Vanhkre expressa intenções, sejam elas sociais, políticas, culturais ou ambientais. Unwin (2013) novamente nos auxilia, por meio da reflexão sobre as condições que promovem a arquitetura, as quais carregam sentido e significado para as pessoas quando correspondem à sua visão de mundo.

No discurso dos entrevistados, percebemos a clara intenção de continuidade cultural e de fortalecimento de sua identidade por meio da edificação escolar, na qual as crianças podem ver refletidos alguns aspectos considerados relevantes e que foram materializados nessa arquitetura. Como apresentaremos a seguir, as formas de uso possibilitadas pela nova escola também traduzem essa intenção.

Tendo em vista a arquitetura resultante desse processo, inspiramonos em Rapoport $(1971,2003)$ para elaborar a seguinte reflexão: será relevante questionar formalmente a solução sob o olhar da arquitetura se a comunidade se sente contemplada pelo projeto? As repostas que obtivemos, em entrevistas, apontam nesta direção: a da satisfação de uma série de quesitos com a construção dessa escola. Os entrevistados também demonstraram sentir orgulho e afeto por esse novo lugar.

Contudo, como em qualquer situação, especialmente pelo passar do tempo, o qual provoca mudanças no contexto da comunidade, hoje identificamos uma série de dificuldades, as quais levaram e levarão a transformações em seus ambientes. Consideramos que essas transformações refletem uma arquitetura viva, vivenciada e adaptável às necessidades que se expressam nos espaços construídos e no seu entorno. As transformações nos espaços, segundo Pol (1996), refletem a apropriação pela ação, expressando o uso e a identificação das pessoas, que, dessa forma, convertem os espaços em lugares significativos.

Unwin (2013, p. 25) argumenta, ainda, que a arquitetura é "influenciada pelas pessoas cujas atividades ela acomoda" (UNWIN, 2013, p. 25). Nesse sentido, somadas às alterações durante o projeto arquitetônico e à execução, destacamos também as alterações posteriores, as quais foram realizadas para manutenção ou adaptação de funções, o que, de certa forma, alterou elementos significativos, conforme pudemos constatar com as entrevistas. Exemplos disso são a retirada dos espaços para o fogo de chão junto às salas de aula e a pavimentação do pátio, o qual era em terra batida, características essas do projeto original. Tais elementos foram destacadas por uma entrevistada como positivos, porque a presença do fogo junto às salas de aula e a possibilidade de pisar na terra ao sair para o exterior aproximavam a escola do modo de vida kaingang. Ela relembra que o fogo de chão também possibilitava que fossem cozidos alimentos enquanto as atividades escolares aconteciam em paralelo, avivando, desse modo, diferentes sentidos relacionados à memória, como o olfato e o paladar (SCHMID, 2005), os quais são capazes de fortalecer o aprendizado. Por sua vez, uma gerente de educação entrevistada afirmou que tanto as lareiras, quanto o pátio de terra, tornavam mais complicadas as atividades de manutenção da escola, revelando diferentes concepções 
estéticas e expectativas com relação ao uso dos espaços. Zanin (2018) questiona, em suas considerações finais, justamente a sobreposição de intenções voltadas aos espaços escolares indígenas devido à interculturalidade que se observa na gestão desses lugares.

Silva e Nötzold (2012) também trazem o relato de alterações realizadas no espaço físico da escola, as quais acabaram influenciando negativamente atividades que fortalecem aspectos culturais, como é o caso da disciplina de Artes. As autoras apresentam entrevistas que ressaltam a pertinência da Sala de Artes, onde os estudantes podiam aprender a confeccionar artesanato, muitas vezes com a participação de outras pessoas da comunidade, além dos professores. Esse espaço caracterizava-se, principalmente, pelo piso de terra (chão batido), que possibilitava o uso do fogo, necessário para a produção do artesanato. Contudo, com o aumento das matrículas e a falta de espaço físico, esse ambiente foi reformado, com a substituição do piso, transformando-o em uma sala de aula como as demais.

A realização de atividades relacionadas à cultura não somente requer espaços construídos especificamente para isso, como também estava prevista para se estender por outros ambientes da comunidade, o que, segundo uma entrevistada, costumava acontecer nos primeiros anos de uso dessa escola. Porém, Silva e Nötzold (2012) destacam as dificuldades enfrentadas pelos professores ao proporem, nas aulas de artes, o aprendizado do artesanato, que demanda percorrer outros ambientes da comunidade para coleta e manejo de matérias-primas. Verifica-se, com isso, uma incompatibilidade relacionada à organização dos tempos e dos espaços requeridos para essas atividades. Nesse sentido, é necessário que o Plano Político Pedagógico (PPP) da escola contemple tanto a diversidade de atividades quanto a diversidade de lugares e de tempos de aprendizagem, com a possibilidade de expandilos para o contexto da comunidade, como descrito em Zanin (2018) ao analisar uma escola Guarani.

Conforme previsto no projeto original, os entrevistados relataram que, nos primeiros anos de utilização das edificações, as atividades artísticas, como apresentações culturais, eram realizadas no Anfiteatro Kaingang. A comunidade recebia estudantes de outras escolas com muita frequência, inclusive pela arquitetura da escola tê-la convertido em uma referência para escolas indígenas. Porém, com o passar do tempo, as estruturas originais do Anfiteatro foram se deteriorando, sem receberem a necessária manutenção, o que impossibilitou a continuidade de uso desse bloco. A comunidade, a partir disso, tem solicitado a recuperação do Anfiteatro, mas sem previsão de receber uma reforma, visto que a escola apresenta outras demandas relacionadas aos espaços físicos.

Outro aspecto que precisa ser aprofundado ao propor novas edificações escolares é a possibilidade de ampliação da escola para acompanhar o crescimento da comunidade. A falta de espaço físico foi relatada como um dos grandes problemas do projeto, pois a escola, que estava prevista para atender 300 alunos, já teve em torno de 1.200 matrículas e, atualmente, possui mais de 700 estudantes matriculados, cursando o Ensino Fundamental, o Ensino Médio e a EJA (Educação de 
Jovens e Adultos). Um entrevistado destacou a dificuldade de diálogo para realizar uma ampliação da edificação escolar que contemplasse as características formais do projeto original, já que no projeto não estava prevista essa possibilidade. Em decorrência disso, viabilizou-se a construção de um "projeto modelo" para laboratórios, que, desde sua execução, vem sendo utilizado como espaço complementar para salas de aula e outras atividades da escola, como ensaios artísticos. Contudo, a nova edificação não dialoga arquitetonicamente com a proposta original, sobrepondo-se pela sua localização e, com isso, desvalorizando a paisagem construída inicialmente (Figura 19).

Figura 19: Ampliação da escola.

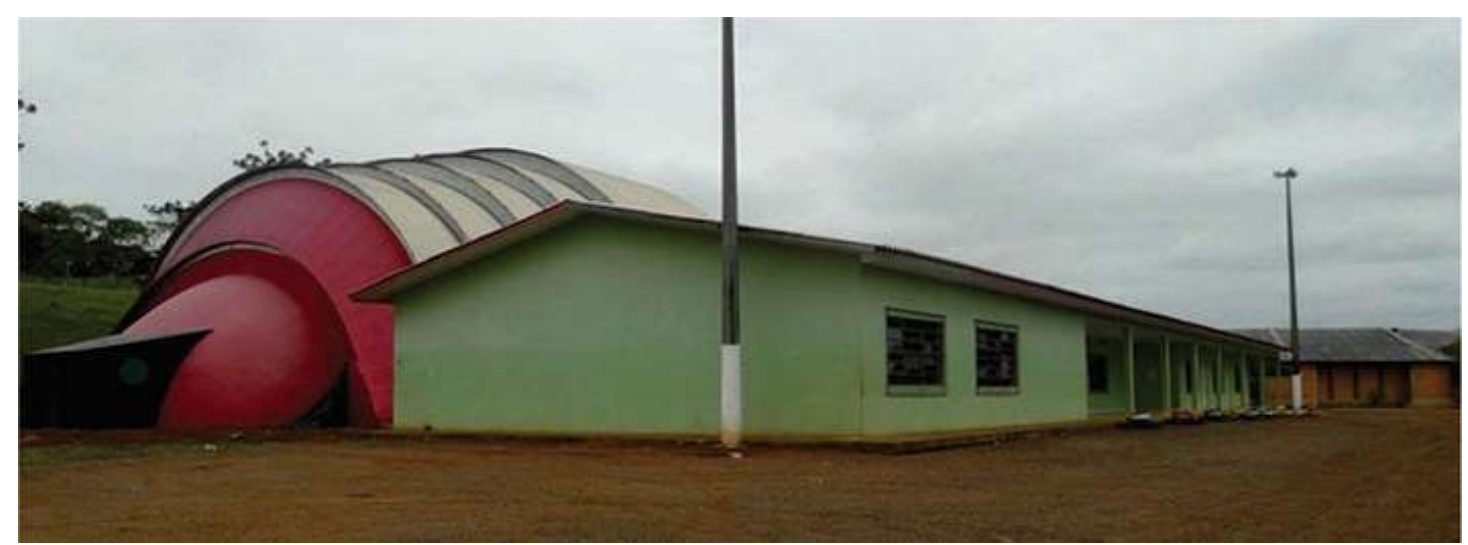

Foto: Fernanda Machado Dill.

\section{Aspectos a considerar}

Detivemo-nos a apresentar a trajetória de uma comunidade indígena a partir das conquistas e das transformações protagonizadas e vivenciadas em seus ambientes escolares. Com a análise desse caso, podemos tecer algumas considerações relacionadas a intervenções de arquitetura em agrupamentos indígenas, como a participação da comunidade em diferentes momentos do processo, inclusive nas transformações decorrentes do uso. Isso permite o aporte de preceitos culturais e facilita a identificação dos usuários com os ambientes. No caso da edificação escolar, ela possibilita maior conexão entre as atividades práticas e o uso dos espaços, facilitando a inclusão de processos próprios de aprendizagem.

$\mathrm{Na}$ fala dos entrevistados, vemos alguns aspectos relevantes, como a utilização de materiais naturais, os quais os aproximam da cultura, desenvolvendo uma relação de afeto com o lugar, por trazerem sensações e despertarem os sentidos, fortalecendo seu modo de vida. Em termos de arquitetura, isso é destacado por vários autores interessados nos significados dos espaços e como as percepções sensoriais vivenciadas podem vincular as pessoas com os lugares (UNWIN, 2013; ZUMTHOR, 2006; SCHMID, 2005; BACHELARD, 1989). 
Apesar disso, observamos dificuldades com relação ao diálogo durante o processo de projeto, ao uso e às transformações dos espaços. Consideramos que uma das maiores dificuldades está relacionada ao conhecimento aprofundado da cultura, o qual poderia ser facilitado com a participação de arquitetos indígenas, a exemplo do que acontece em outros países (MALNAR \& VODVARKA, 2013; KRINSKI, 1996). Outro aspecto relevante é a previsão de ampliação da área construída, para que ela possa contemplar demandas futuras.

O caso da EIEB Cacique Vanhkre representou a materialização de um grande avanço, o qual foi originado dos movimentos em defesa da educação indígena. Ainda assim, poderíamos vislumbrar modificações mais profundas no sistema convencional de ensino para contemplar especificidades culturais. Assim como observamos que no contexto de cada comunidade a arquitetura escolar é específica, também o são os modos de ensinar. E é nesse ponto que reside a complexidade das intervenções arquitetônicas em comunidades indígenas: em sua singularidade. 


\section{Referências bibliográficas}

ALTINI, E. et al. (Orgs.). Por uma Educação descolonial e libertadora: manifesto sobre a educação escolar indígena no Brasil. Brasília: CIMI, 2014. Disponível em: $<$ http://cimi.org.br/pub/MS/escolas/ManifestoEduca.pdf $>$. Acesso em: $31 \mathrm{dez} .2014$.

BACHELARD, G. A poética do espaço. Tradução de Antônio de Pádua Danesi. São Paulo: Martins Fontes, 1989.

BALDUS, H. Ensaios de etnografia brasileira. São Paulo: Companhia Nacional, 1937.

BORBA, T. Actualidade indígena. Coritiba: Typ e Lytog a Vapor impressora Paranaense, 1908.

BRASIL. Constituição da República Federativa do Brasil de 1988. Disponível em: $<$ http://www.trtsp.jus.br/legislacao/constituicao-federal-emendas $>$. Acesso em: 16 maio 2016 .

BRASIL. Decreto n⿳ 26, de 4 de fevereiro de 1991. Dispõe sobre a Educação Indígena no Brasil. Diário Oficial da União, Brasília, DF, 1991.

BRASIL. Decreto n. ${ }^{\circ}$ 6.861, de 27 de maio de 2009. Dispõe sobre a Educação Escolar Indígena, define sua organização em territórios etnoeducacionais e dá outras providências. Diário Oficial da União, Brasília, DF, 2009.

BRASIL. Lei n. ${ }^{\circ}$ 9.394, de 20 de dezembro de 1996. Estabelece as diretrizes e bases da educação. Diário Oficial da União, Brasília, DF, 1996.

BRASIL. Lei n. ${ }^{\circ}$ 13.005, de 25 de junho de 2014. Aprova o Plano Nacional de Educação - PNE e dá outras providências. Diário Oficial da União, Brasília, DF, 2014.

BRASIL. Ministério da Educação. Plano Nacional de Educação. Brasília: Inep, 2014.

BRASIL. Ministério da Educação. Secretaria de Educação Continuada, Alfabetização e Diversidade. Educação escolar indígena: diversidade sociocultural indígena ressignificando a escola. Cadernos SECAD 3. Brasília, DF: SECAD/MEC, 2007.

CARRINHO, R. G. Habitação de interesse social em aldeias indígenas: uma abordagem sobre o ambiente construído Mbyá-guarani no litoral de Santa Catarina. 2010. Dissertação (Mestrado) - Centro Tecnológico, Programa de Pós-Graduação em Arquitetura e Urbanismo, Universidade Federal de Santa Catarina, Florianópolis, 2010.

CARVALHO, B. M. de. Intervenções habitacionais em comunidades tradicionais: uma solução ou um problema? In: ENCONTROS NACIONAIS DA ANPUR 15 (2013). Anais... $<$ http://unuhospedagem.com.br/revista/rbeur/index.php/anais/article/viewFile/4530/439 9>. Acesso em: 22 maio 2014. 
COSTA, M. H. F.; MALHANO, H. B. Habitação indígena brasileira. In: RIBEIRO, B. Suma Etnológica Brasileira 2 - Tecnologia indígena. Petrópolis: Vozes/Finep, 1987. p. 27-92.

D'ANGELIS, W. R.; VEIGA, J. Habitação e acampamentos Kaingang hoje e no passado. Cadernos do CEOM, n. 18, 213-242.

DALMOLIN, G. F. O papel da escola entre os povos indígenas da Amazônia Ocidental: de instrumento de exclusão a recurso para emancipação sociocultural. 2004. 267 f. Tese (Doutorado em Educação) - Programa de Pós-Graduação em Educação, Universidade Federal de São Carlos, São Carlos, 2004.

KRINSKY, C. H. Contemporary Native American Architecture: cultural regeneration and creativity. New York: Oxford University Press. 1996.

KELLER, F. Noções sobre os indígenas da Província do Paraná. Manuscrito de 1867 sob guarda do Arquivo Nacional. Rio de Janeiro: Museu do Índio, 1974.

ISA Instituto Socioambiental de Olho nas Terras Indígenas. São Paulo. 2016.

MANFROI, N. M. S. Professor Felicíssimo Belino e a primeira escola para os Kaingáng: a memória compondo a história e a história registrando a memória. In: NÖTZOLD, A. L. V.; ROSA, H. A.; BRINGMANN, S. F. (Orgs.). Etnohistória, história indígena e educação: contribuições ao debate. Porto Alegre: Palotti, 2012. p. 107-122.

MALNAR, J. M.; VODVARKA, F. New Architecture on Indigenous Lands. Minneapolis: University of Minnesota, 2013.

MULTIPLICA. (06 de março de 2016). Casas subterrâneas do povo Kaingang. Acesso em: 12 mar. 2016. Disponível em: MULTIPLICA <http://multiplica.org/subterraneas-dopovo-kanghag/>.

NACKE, A.; BLOEMER, N. M. S. As áreas indígenas Kaingang no oeste catarinense. In: Os Kaingang no oeste catarinense: Tradição e atualidade. Chapecó: Argos, 2007.

NÖTZOLD, A. L. V. Nosso vizinho Kaingang. Florianópolis: UFSC, 2003.

NÖTZOLD, A. L. V. O ciclo de vida Kaingang. Florianópolis: UFSC, 2004.

NÖTZOLD, A. L. V; ROSA, Helena Alpini. Desafios para a Autonomia na Educação Escolar Indígena. In: Rev. Teoria e Prática da Educação, v. 16, n. 2, p. 35-45, maio/ago. 2013.

NOVAES, S. C. (Org.) Habitações indígenas. São Paulo: Nobel/Editora da Universidade de São Paulo, 1983.

PIOVEZANA, L. Território Kaingang na Mesoregião Grande da Fronteira do Mercosul. Tese (Doutorado) - UNISC, 2010. 
POL, E. La apropriación del espacio. In: L. Iñiguez; E. Pol. Cognición, representación y apropiación del espacio. Barcelona: Publicacions Universitat de Barcelona, 1996. p. $45-62$.

RAMOS, Alcida Rita. Sociedades indígenas. São Paulo: Ática, 1995.

RAPOPORT, A. Hechos y Modelos. In: G. BROADBENT. Metodologia del Diseño Arquitectonico. Barcelona: Editorial Gustavo Gili, 1971.

RAPOPORT, A. Cultura, Arquitectura y Diseño. Arquitectonics. Mind, land \& society. Barcelona: Edicions UPC, 2003.

REIS, M. J. (2007). A problemática arqueológica das estruturas subterrâneas no Planalto Catarinense. Erechim: Sociedade e arqueologia brasileira, 2007.

ROSA, H. A. A trajetória histórica da escola na comunidade Guarani de Massiambu, Palhoça/SC - Um Campo de Possibilidades. 2009. Dissertação (Mestrado) - Programa de Pós-Graduação em História, Centro de Filosofia e Ciências Humanas, Universidade Federal de Santa Catarina, Florianópolis.

SANTOS, S. C. Organização e atividades de assistência governamental aos índios. In: Educação e Sociedades Tribais. Porto Alegre: Movimento, 1975.

SCHMITZ, P. et al. Casas subterrâneas no Planalto de Santa Catarina: São José do Cerrito. Pesquisas: Série Antropologia n. 18, 7-78.

SCHMID, A. L. A ideia de conforto: reflexões sobre o ambiente construído. Curitiba: Pacto Ambiental, 2005.

SECRETARIA da Educação e do Desporto de Santa Catarina. Educação escolar indígena em Santa Catarina: construindo a cidadania (folheto). Florianópolis: SED/SC, 2002. Disponível em: <http://biblioteca.funai.gov.br/media/pdf/Folheto65/FO-CX-654329-2011.pdf>. Acesso em: 22 mar. 2020.

SILVA, I. L. Projeto Arquitetônico $\mathbf{n}^{\mathbf{0}}$ 2000: Colégio Estadual Vitoriano Kondá [Relatório] - Florianópolis: Governo do Estado de Santa Catarina, 1999.

SILVA, L. A. A história Kaingang através do Ritual do Kiki. Santa Catarina em História, 11-23, 2011.

SILVA, L. M.; NÖTZOLD, A. L. V. História Oral e Cultura Material Kaingáng: um olhar sobre a tradição e o ambiente escolar. In: XI ENCONTRO NACIONAL DE HISTÓRIA ORAL - Memória, Democracia e Justiça, 2012, Rio de Janeiro. Anais eletrônicos, 2012. Disponível em: $<$ https://www.encontro2012.historiaoral.org.br/site/anaiscomplementares $>$. Acesso em: 22 mar. 2020.

TASSINARI, A. M. I. A educação escolar indígena no contexto da antropologia brasileira. Ilha Revista de Antropologia, [s.1.], v. 10, n. 1, p. 217-244, ago. 2008. 
TOMMASINO K.; FERNANDES R. C. Povos indígenas no Brasil. Janeiro de 2001. Disponível em: <http://pib.socioambiental.org/pt/povo/kaingang //> Acesso em: $30 \mathrm{de}$ nov. de 2015.

TOMMASINO K. A história dos Kaingang da Bacia dos Tibagi: Uma sociedade Jê Meridional em movimento. 1995. Tese (Doutorado em Antropologia Social) Universidade de São Paulo, 1995.

UNWIN, S. A análise da arquitetura. Tradução: Alexandre Salvaterra. Porto Alegre: Bookman, 2013.

VEIGA, J. (2000). Cosmologia Kaingang e suas práticas rituais. XXIV Encontro Anual da Anpocs. Disponível em: $<$ https://www.anpocs.com/index.php/encontros/papers/24-encontro-anual-da-anpocs/gt22/gt04-12/4742-jveiga-cosmologia/file>. Acesso em: 11 maio 2020.

ZANIN, Nauíra Zanardo. Abrigo na natureza: construção Mbyá-Guarani, sustentabilidade e intervenções externas. 2006. Dissertação (Mestrado) - Programa de Pós-Graduação em Engenharia Civil, Escola de Engenharia, Universidade Federal do Rio Grande do Sul, Porto Alegre, 2006.

ZANIN, N. Z.; SILVA. I. M. M.; CRISTOFOLI, M. S. 2018. Espaços escolares indígenas no Brasil: políticas, ações e atores envolvidos. In: Educação \& Realidade, Porto Alegre, v. 43, n. 1, p. 201-222, jan./mar. 2018.

ZANIN, N. Z. Intervenções arquitetônicas junto a povos indígenas: processo de projeto, apropriação e uso de ambientes escolares. Tese (Doutorado) - Programa de Pós Graduação em Arquitetura e Urbanismo, Universidade Federal de Santa Catarina, Florianópolis. 2018.

ZUMTHOR, P. Atmosferas: entornos arquitectónicos: as coisas que me rodeiam. Traduzido por A. Grabow. Barcelona: Editorial Gustavo Gili, 2006.

Recebido em: 12/05/2020 * Aprovado em: 16/09/2020 * Publicado em: 28/04/2021 